\title{
A percepção de crianças do ensino fundamental sobre parada cardiorrespiratória
}

\section{The perception of children of elementary education about cardiorespiratory arrest}

\author{
Mariélli Terassi ${ }^{1}$; Adrielle Karine Pesce Guerra Borges ${ }^{2}$; Mara Lucia Garanhani ${ }^{3}$; \\ Eleine Aparecida Penha Martins ${ }^{4}$
}

\begin{abstract}
Resumo
A parada cardiorrespiratória é uma situação grave e frequente na sociedade, sendo de fundamental importância a capacitação da população em geral para o seu atendimento. Objetivando conhecer a percepção de crianças sobre parada cardiorrespiratória, realizou-se uma pesquisa de natureza qualitativa, com crianças de 8 a 10 anos, matriculadas em uma escola privada de ensino com proposta construtivista. A coleta dos dados ocorreu entre os meses de outubro e novembro de 2013, por meio de entrevista coletiva gravada. Como critério para a inclusão os alunos deveriam estar matriculados na instituição e aceitarem participar da pesquisa mediante consentimento do responsável. Participaram do estudo 31 crianças. Os alunos foram divididos em quatro turmas: $5^{\circ}$ ano, $4^{\circ}$ ano, $3^{\circ}$ ano $\mathrm{A} \mathrm{e} 3^{\circ}$ ano $\mathrm{B}$, com média de 08 alunos em cada turma. As entrevistas foram analisadas utilizando como método a análise de conteúdo de Bardin. A partir dos discursos emergiram duas categorias: Conhecimento prévio das crianças sobre parada cardiorrespiratória e o saber agir frente à situação de parada cardiorrespiratória. As crianças associam o evento de parada cardiorrespiratória à parada súbita das funções do coração, do pulmão ou de ambos e relataram que chamar ajuda é uma das principais ações a serem realizadas se uma pessoa encontra-se inconsciente. Observou-se que os alunos do $5^{\circ}$ ano possuíam conhecimento prévio mais elaborado que os demais. A abordagem da temática nas escolas mostrou-se positiva, contribuindo para a troca de experiências, conscientização e construção de novos saberes, devendo portanto ser continuada.
\end{abstract}

Palavras-chave: Crianças. Parada cardíorrespiratória. Educação em saúde.

\begin{abstract}
Cardiorespiratory arrest (CRA) is a serious situation that occurs frequently in public environments, which makes assistance training of the general population of great importance. The objective was to understand the perception of children on CRA. Qualitative research conducted with children 8-10 years old enrolled in a private elementary school with a constructive proposal. Data collection occurred between the months of October and November 2013 in a recorded collective interview. As a criterion for inclusion students should be enrolled in the institution and accept to participate in the research with the consent of a guardian. Thirty
\end{abstract}

\footnotetext{
${ }^{1}$ Enfermeira Especialista em Cuidados Intensivos do Programa de Residência da UEL e Mestranda em Enfermagem da UFSCAR. ${ }^{2}$ Especialista em Saúde Coletiva e Saúde da Família. Mestranda em Enfermagem da Universidade Estadual de Londrina.

${ }^{3}$ Enfermeira, doutora em Enfermagem pela Escola de Enfermagem de Ribeirão Preto, USP. Docente do departamento de Enfermagem da Universidade Estadual de Londrina.

${ }^{4}$ Enfermeira, doutora em Enfermagem fundamental pela Escola de Enfermagem de Ribeirão Preto, USP. Docente do departamento de enfermagem da Universidade Estadual de Londrina.
} 
children participated in the study. The students were divided into four groups: 5th year, 4th year, 3rd year A and 3rd year B, with an average of 08 students per group. The interviews were analyzed using the Bardin content analysis methodology. From the speeches, two categories emerged: Child's prior knowledge on CRA and how to act on the event of a CRA. Children associate the event of sudden CRA to a condition in which the heart and/or lungs suddenly stop acting. Seeking emergency assistance was reported as one of the main actions to be taken if a person is unconscious. It was observed that the 5th graders had best prior knowledge about the topic CRA when compared to students in the 3rd year. The thematic approach of CRA in schools contributes to the exchange of experiences, awareness of children and building new knowledge-oriented health education.

Keywords: Child. Cardiorespiratory arrest. Health education.

\section{Introdução}

As doenças relacionadas ao sistema cardiovascular constituem um agravo de ordem global. No Brasil, no ano de 2007, os óbitos decorrentes de doenças do aparelho circulatório totalizaram 308 mil, superando as mortes por neoplasias, causas externas e doenças respiratórias (BRASIL, 2014). A parada cardiorrespiratória (PCR) representa a principal causa de morte em vários países (LYRA et al., 2012), e pode ser definida como uma condição súbita, que causa a interrupção das atividades respiratórias e cardíacas, levando a uma deficiência absoluta de oxigenação tissular no indivíduo (LUZIA; LUCENA, 2009).

A identificação precoce da vítima em PCR, o acionamento da equipe de emergência e o inicio imediato das manobras de ressuscitação cardiopulmonar (RCP) favorecem o prognóstico do paciente (BERDOWSKI et al., 2009). Entretanto, grande parte da população não está preparada para prestar este atendimento, pois não tem conhecimento acerca do assunto (LYRA et al., 2012). Essa questão norteou um estudo, realizado em uma cidade no interior do Estado de São Paulo, que evidenciou que a população leiga não realiza massagem cardíaca por desconhecimento, medo de fazer algo errado ou de adquirir alguma doença infectocontagiosa (PERGOLA; ARAUJO, 2008).

Observa-se a necessidade de realizar a capacitação da população em geral no tema primeiros socorros, e, dentro deles as manobras de RCP. O processo de educação é um ato contínuo que requer tempo e dedicação, tornando-se recomendável iniciar as orientações ainda na infância, como uma forma de multiplicar os conhecimentos à população e contribuir para um atendimento adequado e seguro (ANDRAUS et al., 2005).

No período da infância, a criança tem a oportunidade de se desenvolver intensamente e isto é favorecido pelas diferentes vivências que tenha presenciado, influenciando diretamente com a formação de ideias, sentimentos, hábitos e traços de sua personalidade. Este desenvolvimento tem influência também do contexto social em que a criança participa, como a escola, igreja e família. Dessa forma, o ensino de primeiros socorros para crianças, atua como facilitador do desenvolvimento de adultos mais preparados para o atendimento de emergências em ambientes extra hospitalares (LIRA; MACHADO; FASSINI, 2011).

A criança passa grande parte do seu dia na escola, em contato com professores e outros alunos, trocando vivências e desvendando novos saberes, por isso, a escola possui papel fundamental na construção de conhecimentos, devendo buscar continuamente estratégias que visem a promoção, prevenção e educação também na área da saúde (IERVOLINO; PELICION, 2005). O processo de educação em primeiros socorros, entre eles a parada cardiorrespiratória, realizada de forma dinâmica e estimulante, desenvolve na criança a tomada de decisão e conduta positivas frente a situações de emergência (IERVOLINO; PELICION, 2005).

Ações educativas na idade escolar favorecem a formação de indivíduos capazes de transformar a 
prática social e transmitir os conhecimentos adquiridos à sociedade (IERVOLINO; PELICION, 2005). A educação no setor de saúde é uma prática fundamental para o processo de construção de conhecimentos em saúde, por meio de ações educativas que têm como objetivo promover na sociedade a inclusão social e a promoção da autonomia dos sujeitos na participação em saúde (BRASIL, 2008). A educação em saúde, pode ser definida como um campo de práticas no qual ocorrem interações entre educador e educando a todo momento, possibilitando o compartilhamento dos saberes e buscando conjuntamente a melhoria da qualidade de vida dos indivíduos (OLIVEIRA; WENDHAUSEN, 2014).

Diante do exposto, objetivou-se analisar a percepção de crianças sobre o tema parada cardiorrespiratória.

\section{Materiais e Método}

Estudo de natureza qualitativa, desenvolvido em uma escola privada de ensino na cidade de Londrina -PR.

A população participante constituiu-se de 31 crianças, estudantes nos $3^{\circ}, 4^{\circ}$ e $5^{\circ}$ anos do ensino fundamental, com idades entre 8 a 10 anos. Como critério para a inclusão, os alunos deveriam estar matriculados na instituição e devolver o Termo de Consentimento Livre e Esclarecido assinado pelo seu responsável. A faixa etária foi selecionada por compreenderem as crianças com maior faixa etária estudantes na instituição, que atende somente até o $5^{\circ}$ ano do ensino fundamental.

A coleta dos dados foi realizada na própria escola, entre os meses de outubro e novembro de 2013, a partir de um cronograma de visitas estabelecido pelas professoras da instituição para não prejudicar as atividades curriculares. Para a coleta dos dados foi utilizada à entrevista coletiva. Os alunos foram divididos em quatro turmas: $5^{\circ}$ ano, $4^{\circ}$ ano, $3^{\circ}$ ano $\mathrm{A} \mathrm{e} 3^{\circ}$ ano $\mathrm{B}$, com média de 08 alunos em cada turma.
Aconteceram dois encontros com cada turma, de 45 minutos de duração cada e intervalo semanal. A entrevista coletiva foi conduzida pela pesquisadora principal, utilizando um instrumento com questões norteadoras. As questões norteadoras foram: $\mathrm{O}$ que vocês fariam se vissem uma senhora caída no chão? Como vocês veriam se ela esta acordada? O que vocês fariam para tentar acordá-la? Vocês acham que deveriam chamar alguém? Quem? Vocês conhecem o Serviço de Emergência? Sabem qual o número de telefone desse serviço? Caso vocês ligassem para o serviço de emergência, que informação vocês acham importante falar? O que vocês fariam para tentar fazer o coração dela voltar a bater? Vocês já viram alguma situação como está?

Após cada pergunta, aguardava-se que as crianças respondessem para então ser feito o questionamento seguinte, objetivando não induzir as respostas com a questão posterior.

A entrevista coletiva também é conhecida como entrevista de grupo e entrevista grupal, a qual é definida por Flick (2007) como sendo uma entrevista realizada com um pequeno grupo de pessoas em que é abordado um determinado assunto ou tópico. Sua composição pode ser formada de 5 a 8 pessoas, com duração de 30 minutos a duas horas. O mesmo autor destaca que a entrevista coletiva é uma técnica altamente eficiente, pois os grupos tendem a se completar e o entrevistador deve manter a observação atenta do grupo, dando voz aos participantes mais calados, impedindo o monopólio e centralização da palavra por um ou dois membros, redirecionando a discussão (FLICK, 2007).

As entrevistas foram gravadas, transcritas na íntegra e analisadas utilizando como método a análise de conteúdo proposta por Bardin, cujo objetivo é descrever o conteúdo das comunicações por meio de procedimentos objetivos e inferências sobre o objeto estudado (BARDIN, 2011). Para análise temática foi adotado as seguintes etapas: pré análise, exploração do material, tratamento 
dos resultados, inferência e interpretação. A partir dessas etapas surgiram duas categorias temáticas: Conhecimento prévio das crianças sobre parada cardiorrespiratória e o saber agir frente à situação de PCR.

A pesquisa foi autorizada pela direção da escola e aprovada pelo Comitê de Ética em Pesquisa Envolvendo Seres Humanos da Universidade Estadual de Londrina, sob CAAE $n^{\circ}$. 19165413800005231. O Termo de Consentimento Livre e Esclarecido foi assinado pelos responsáveis pela criança, em duas vias, ficando uma em posse dos pesquisadores e a outra com o responsável pelo aluno.

O artigo faz parte dos resultados de uma dissertação de Mestrado do Programa de Mestrado em Enfermagem da Universidade Estadual de Londrina.

\section{Resultados e Discussão}

Os alunos foram identificados pela letra A seguido por um numeral, com o objetivo de garantir anonimato, ficando da seguinte maneira: $5^{\circ}$ ano $\mathrm{A} 1$ à $\mathrm{A} 7 ; 4^{\circ}$ ano- $\mathrm{A} 8$ à $\mathrm{A} 15 ; 3^{\circ}$ ano $\mathrm{A} 16$ à $\mathrm{A} 31$. O $3^{\circ}$ ano obteve o maior número de participantes pois a autora optou por entrevistar a totalidade de alunos matriculados nos três anos selecionados.

A idade das crianças variou entre 8 a 10 anos. Dos 31 alunos, a maioria era do sexo feminino, possuíam pelo menos 1 irmão, participavam de alguma atividade extraescolar como natação, dança, música e esportes, eram filhos de pais não profissionais da área da saúde e referiram como fonte de busca de informações os pais, professores, televisão e internet.

Dos sujeitos participantes, nenhum recebeu treinamento ou havia participado de atividades sobre a temática anteriormente. A participação prévia não foi considerada um critério de exclusão para a pesquisa, visto que o objetivo desta foi conhecer a percepção e o entendimento dos alunos sobre o tema.
Observou-se, ao iniciar o levantamento bibliográfico uma lacuna de conhecimento no tema em publicações nacionais. Poucas são as referências que abordam os primeiros socorros com alunos do ensino fundamental.

Os alunos do $5^{\circ}$ ano relataram durante a entrevista melhor conhecimento prévio sobre o tema quando comparado aos alunos do $3^{\circ}$ ano. Esse fato pode ser explicado pelas vivências e conhecimentos adquiridos, pela própria maturação biológica do ser humano, como também pela maior facilidade de associação do aprendizado por crianças mais velhas. Toda a criança apresenta evolução do seu desenvolvimento, nesse sentido, a criança avança mais etapas no processo de aprendizado conforme sua faixa etária progride (SILVA, 2012).

Do processo de análise dos relatos foi possível a emersão das seguintes categorias: Conhecimento prévio das crianças sobre parada cardiorrespiratória e o saber agir frente à situação de PCR.

\section{I: Conhecimento prévio das crianças sobre parada cardiorrespiratória}

Esta categoria aborda o conhecimento prévio das crianças sobre parada cardiorrespiratória e a função do coração na percepção dos alunos. Os resultados encontrados demonstraram um conhecimento superficial dos alunos sobre PCR.

Os participantes relacionaram a parada cardiorrespiratória à cessação súbita de atividades do coração, do pulmão ou de ambos, como descrito a seguir.

[...] É quando o coração para de bater [...] (A1).

[...] Quando o coração para [...] (A8).

[...] Quando para de respirar [...] (A13).

[...] Parada cardíaca é quando uma pessoa para de respirar [...] (A24).

[...] Eu também acho que as vezes para de respirar. E para de bater o coração [...](A28).

[...] Meu tio já teve uma parada e daí eu acho que é quando o coração para de bater e para de respirar [...] (A30). 
A PCR é definida de diversas maneiras na literatura, mas todos os autores salientam o elevado índice de gravidade e que pode gerar consequências negativas para a vida do paciente ou seu prognóstico. Segundo Luzia e Lucena (2009) e Santos e Rodrigues (2011), a PCR refere-se à interrupção súbita da respiração e circulação sanguínea, com consequente colapso hemodinâmico, caracterizando-se como uma situação de risco iminente de vida, que requer a tomada de ação imediata.

A PCR acomete principalmente indivíduos adultos do sexo masculino, com comorbidades associadas ao sistema cardiovascular, choque séptico, tromboembolismo pulmonar e falência cardíaca. Em adultos jovens, o trauma ocupa a segunda causa mais frequente de PCR e, na população infantil a ocorrência de PCR está mais associada a agravos respiratórios (FERREIRA; FERREIRA; CASSEB, 2012).

Percebe-se nas falas das crianças a importância da função cardíaca na manutenção da vida.

[...] Não sei se ele produz, mas o que eu sei do coração é que bombeia o sangue pelas artérias para o corpo (A9).

[...] Artéria é a que leva o sangue limpo para as partes e a veia é a que tira o sangue sujo [...] (A10).

[...] Sem o coração a gente não vive e se parar a gente ...morre [...] (A16).

[...] Quando para o coração, fica com falta de ar, seu sangue para, sua voz começa a ficar meio rouca [...] (A20).

[...] fica bombeando sangue por uma válvula que leva para as veias $[\ldots]$ (A24).

Observou-se, nas falas, um paralelo entre termos científicos e o senso comum. As crianças citam termos como válvulas, artérias, veias, ao mesmo tempo em que expressam um conceito simplificado sobre a função cardíaca. Nota-se nas falas dos alunos do $4^{\circ}$ ano maior conhecimento cientifico sobre o assunto comparando com o $3^{\circ}$ ano.
O senso comum que retrata o coração como órgão fundamental no processo vital é compartilhado por toda a população. Os alunos expressam um saber não técnico, refletindo por meio das falas o saber associado ao imaginário social. Esse saber está relacionado as questões diárias que as crianças são expostas, a compreensão e associação daquilo que já se conhece com as novas informações. Nas conversas diárias com a família, amigos e na escola os alunos são expostos a diversas interações sociais, na qual novas representações são produzidas (SILVA et al., 2012).

Nesta perspectiva, a escola tem papel fundamental no desenvolvimento de programas de educação em saúde. O espaço escolar propicia um ambiente para construção de vivências em diversas áreas do conhecimento.

Os programas em educação devem contribuir para o enfoque integral de saúde, no qual o aluno desenvolve a capacidade de adquirir hábitos saudáveis e a reflexão perante os acontecimentos cotidianos envolvendo sua própria saúde e a da comunidade (GOMES; MERHY, 2011; IERVOLINO; PELICIONI, 2005).

A participação de alunos do ensino fundamental e médio em oficinas de capacitação para o atendimento de primeiros socorros, desenvolvidas por profissionais da saúde em escolas públicas e privadas contribuem para a transformação social. Os alunos compartilham os novos saberes com as pessoas que estão ao seu redor e, dessa forma agem em benefício da sociedade (SILVA et al., 2012).

Estudo realizado na cidade de Goiás, com crianças de 8 a 11 anos sobre primeiros socorros e prevenção de acidentes concluiu que, as crianças após participarem dos treinamentos, tiveram importante percentual de acertos em questões referentes ao atendimento em situações de emergência quando comparado ao percentual de acertos, com as mesmas questões, antes de serem ministradas as palestras. O estudo também constatou a importância de implementar estratégias lúdicas 
para ensinar as crianças sobre primeiros socorros, como a dramatização e teatro com fantoches, enfatizando que ensinar brincando é uma estratégia eficiente no aprendizado dos alunos (ANDRAUS et al., 2005).

No período da infância a brincadeira é a principal atividade realizada pelas crianças. $\mathrm{O}$ ato de brincar contribuiu para a aprendizagem e o desenvolvimento infantil no âmbito individual e social (CORDAZZO; VIEIRA, 2007, COSCRATO; PINA; MELLO, 2010). A brincadeira pode ser um instrumento utilizado por professores e profissionais da saúde para educação dos alunos.

Aludoeducação, que refere-se ao educar por meio de brincadeiras é um conceito que vem ganhando espaço nas escolas. Através da brincadeira os professores podem desenvolver novas habilidades nos alunos e discutir temas relacionados também à saúde, entre eles, primeiros socorros (CORDAZZO; VIEIRA, 2007).

\section{O saber agir frente à situação de PCR}

Nessa categoria as crianças expressaram seus conhecimentos frente à situação de PCR e a maneira como agiriam na mesma. Os relatos dos alunos demonstraram que, chamar ajuda é uma das principais ações que eles realizariam caso encontrassem uma pessoa inconsciente, como pode ser evidenciado nos seguintes trechos:

[...] Eu acho que também chamaria a ambulância ou chamaria o primeiro adulto que visse por perto [...] (A4)

[...] Eu, primeiro, eu, assim, eu ligaria para o 192, e daí se eu não soubesse o que estava acontecendo ali eu ia sei lá, falar que encontrei a pessoa lá e ia ver o que eu podia fazer, daí se ele falasse para fazer a massagem e tal, aí eu ia fazer [...] (15).

[...] Eu ia primeiramente ver se está bem, depois eu chamaria a ambulância e veria se ela está respirando[...] (A14).

[...] Primeiro eu ia ver o que estava acontecendo e daí, se estivesse acontecendo, eu chamaria um adulto ou ambulância com médico [...] (A6).
[...] Eu ia chamar outra pessoa para me ajudar [...] (A21).

[...] Eu ia, se eu não tivesse o telefone, celular por perto eu ia ver se tinha algum orelhão por perto, porque no orelhão tem números de emergência [...] (A3).

A população, diante do stress ocasionado por um evento de PCR, geralmente demora a acionar o serviço de emergência e iniciar as manobras de RCR, fato que poderia ser minimizado se os sujeitos recebessem capacitações adequadas.

Nos depoimentos observa-se que as crianças não têm conhecimento sobre a sequência das intervenções que são preconizadas no suporte básico de vida (SBV), porém os alunos relatam e enfatizam a importância de chamar ajuda precocemente. Estudo realizado em Cabo FrioRJ, sobre SBV com alunos do ensino médio, obteve resultado semelhante a respeito das ações realizadas pelos estudantes em situações de emergência (SILVA et al., 2012).

No presente estudo, as crianças associam o saber agir em situações críticas à chamada do serviço de emergência especializado e também na necessidade de procurar acalmar a vítima. Apesar de constituírem como ações essenciais para a RCP, as crianças também devem conhecer e saber iniciar as manobras preconizadas pelo SBV, objetivando promover uma maior sobrevida à vitima.

O Suporte Básico de Vida é um conjunto de ações que constituem as etapas do atendimento em uma PCR, podendo ser iniciado no ambiente extra-hospitalar pela população leiga em geral, desde que recebam um treinamento ou tenham o conhecimento dos procedimentos que devam ser realizados (PERGOLA; ARAUJO, 2008).

Nessas situações, a avaliação e o atendimento precoce devem ser eficazes, contribuindo para a sobrevida da vítima. A sobrevivência a este evento depende de uma série de intervenções fundamentais, que correspondem à "corrente de sobrevivência" (AMERICAN HEART ASSOCIATION, 2010). 
A cada cinco anos as medidas de SBV são atualizadas, a partir do consenso de especialistas e baseados em evidências científicas. No ano de 2010, a American Heart Association (AHA) divulgou novas diretrizes sobre este atendimento, proporcionando intervenção mais simplificada e de alta qualidade (AMERICAN HEART ASSOCIATION, 2010).

As novas diretrizes propostas pela AHA recomendam a rápida identificação da $\mathrm{PCR}$, o acionamento imediato do serviço de emergência, o início precoce das compreensões torácicas que devem ser ininterruptas, favorecendo desta forma a oferta de fluxo sanguíneo para os órgãos e tecidos. Para a população leiga, as diretrizes encorajam somente as compressões torácicas até a chegada dos profissionais de saúde, visto que é uma ação simples de ser executada por indivíduos não treinados e pode ser facilmente instruída por telefone pelo atendente do Serviço Médico de Emergência (AMERICAN HEART ASSOCIATION, 2010).

Ressalta-se a importância de se orientar a população sobre a maneira correta de acionar o serviço de emergência, pois essa etapa frequentemente é negligenciada devido ao desconhecimento e a ansiedade no momento do evento (BERDOWSKI et al., 2009). Porém, as crianças do estudo enfatizam em suas falas a importância do acionando do serviço de emergência ou a ajuda de um adulto para realizar a ligação.

Um estudo com o objetivo de investigar o conhecimento da população adulta sobre SBV, realizado na cidade de São Paulo, constatou que apenas $16,4 \%$ dos indivíduos entrevistados responderam de maneira correta as manobras para facilitar a respiração (PERGOLA; ARAUJO, 2008). Em relação às compressões torácicas $47,5 \%$ não sabiam como realizá-las e 64,7\% referiram não ter conhecimento sobre a quantidade de compressões (PERGOLA; ARAUJO, 2008).
Como já mencionado, as crianças associam os sinais de PCR também à ausência de movimentos respiratórios, como nos depoimentos a seguir:

\section{[...] Tem que ver se está respirando, coração batendo [...] (A3). \\ [...] Ia ver se tá batendo o coração [...](A2). \\ [...] por a mão na frente do nariz e da boca para ver se está respirando...não sei, ia tentar. Eu não sei, a massagem eu não sei do que realmente, o que fazer [...] (A9). \\ [...] Colocar a mão aqui em baixo do nariz [...] (A7). \\ [...] Para ver se está respirando, eu colocaria a mão na frente do nariz e eu não sei como faz uma massagem [...] (A14).}

Nos depoimentos dos alunos, é possível observar a compreensão da parada do coração e pulmão relacionados aos sinais de PCR. As crianças não fazem menção a termos técnicos ou intervenções mais complexas, como a verificação do pulso carotídeo. Este fato pode estar relacionado a idade dos alunos e suas compreensões sobre partes e estruturas do corpo humano.

O aprendizado das crianças está vinculado às experiências e vivências do mundo a sua volta. A vivência de situações variadas favorece o aprendizado e estimula a criança no seu desenvolvimento e amadurecimento (SILVA, 2012).

Os meios de comunicação, como a televisão e a internet fazem parte do cotidiano das crianças e pré-adolescentes, contribuindo para a difusão de informações e conhecimentos muitos dos quais equivocados e incorretos.

Na chamada terceira infância que compreende a faixa etária entre 7 e 11 anos, as crianças começam a pensar suas ações, elaborar seu raciocino e visão crítica, e o acesso aos meios de comunicação são uma ferramenta importante 
para auxiliar na difusão de conhecimentos, inclusive em primeiros socorros (RIBEIRO; BATISTA, 2010).

Várias questões são levantadas sobre a capacidade física e cognitiva das crianças para atuarem de maneira efetiva e correta em situações de emergência. Estudos com crianças de diversas idades vêm sendo realizados com o objetivo de definir em quais idades seria mais adequado ensinar sobre primeiros socorros (MIRANDA, 2011). Segundo Fleischhackl et al. (2009), crianças entre 8 e 9 anos são capazes de realizar medidas de intervenções em primeiros socorros, inclusive para o manuseio do desfibrilador automático externo. Entretanto, algumas instituições defendem que o desenvolvimento de programas para crianças devem ter início a partir dos 11 anos (BRITISH RED CROSS, 2010).

A educação é um importante instrumento para promover a saúde e desenvolver estratégias de prevenção a agravos, tornando-se essencial difundir para a população informações que possam contribuir em eventos emergenciais. Além disso, investir na educação em primeiros socorros, entre eles a RCP, é também uma maneira de diminuir os gastos na saúde pública, pois com o atendimento imediato lesões graves poderiam ser evitadas, assim como os tratamentos de alto custo (THE INTERNATIONAL FEDERATION OF RED CROSS AND RED CRESCENT SOCIETIES, 2010).

A inclusão de oficinas nas escolas para preparar os alunos para o atendimento a vítimas de PCR é vista como a melhor maneira de conscientizar um número elevado de pessoas e repassar os conhecimentos para a população em geral, porém, apesar disso e de todos os aspectos ressaltados anteriormente sobre a importância da educação em primeiros socorros no ambiente escolar, pesquisas feitas em 2010 no continente europeu, revelaram que ainda são escassos os países que incluem nos currículos escolares esta matéria de forma consolidada (INTERNATIONAL FEDERATION OF RED CROSS AND RED CRESCENT SOCIETIES, 2010). Esta realidade aplica-se também ao Brasil, que devido a inexistência de uma legislação que regulamente a prática, o conteúdo não é abordado de modo compulsório nas escolas.

\section{Considerações Finais}

A parada cardiorrespiratória é uma situação grave, que pode ocorrer tanto em ambiente intra hospitalar quanto em ambientes públicos, acarretando altos índices de mortalidade na população mundial. Tendo em vista a relevância do agravo, considera-se o ensino de primeiros socorros fundamental para o atendimento adequado pela população leiga, incluindo crianças.

Os estudantes relataram conhecimento superficial sobre parada cardiorrespiratória, e conceituaram o evento a parada súbita das funções do coração, do pulmão ou de ambos. As crianças do $5^{\circ}$ ano demonstraram conhecimento prévio mais profundo sobre o tema quando comparadas aos do $3^{\circ}$ e $4^{\circ}$ anos.

Outro levantamento importante do estudo foi a constatação de que as crianças consideram importante acionar o serviço de emergência ou a ajuda de um adulto como ação prioritária frente à $\mathrm{PCR}$.

Conclui-se que a abordagem da temática PCR nas escolas de ensino fundamental é relevante, contribuindo para a troca de experiências, conscientização das crianças e construção de novos conhecimentos.

Como limitação da pesquisa ressalta-se a escassez de material nacional sobre o tema.

Os autores acreditam na contribuição da pesquisa para subsidiar novas reflexões dos 
profissionais de saúde e das escolas para o desenvolvimento de estratégias que visem a conscientização e capacitação da população leiga em geral, incluindo os escolares em SBV.

\section{Referências}

AMERICAN HEART ASSOCIATION-AHA. Destaques das diretrizes da American Heart Association 2010 para RCP e ACE. 2010. Disponível em: $<$ http://www.heart.org/idc/ groups/heartpublic/@wcm/@ecc/documents/ downloadable/ucm_317343.pdf $>$. Acesso em: 6 jan. 2014.

ANDRAUS, L. M. S.; MINAMISAVA, R.; BORGES, I. K.; BARBOSA, M. A. Primeiros Socorros para criança: relato de experiência. Acta Paulista de Enfermagem, São Paulo, v. 18, n. 2, p. 220-225, 2005.

BARDIN, L. Análise de conteúdo. São Paulo: Edições 70, 2011.

BERDOWSKI, J.; BEEKHUIS, F.; ZWINDERMAN, A. H.; TIJSSEN, J. G.; KOSTER, R. W. Importance of the first link: description and recognition of an out-of hospital cardiac arrest in an emergency call. Circulation, Dallas, v. 119, n. 15, p. 2096-2102, 2009.

BRASIL. Ministério da Saúde. Secretaria de Gestão do Trabalho e da Educação na Saúde. Glossário temático: gestão do trabalho e da educação na saúde. Brasília: Ministério da Saúde, 2008.

BRASIL. Ministério da Saúde. Secretaria Executiva. Datasus: informações de saúde epidemiológicas e morbidade. Disponível em: $<$ http://www2.datasus.gov.br/DATASUS/index. php?area $=0203>$. Acesso em: 10 out. 2014.

BRITISH RED CROSS. Life: live it education kit. 2010. Disponível em: <http://shop.redcross. org.uk/shop/product.asp? $\mathrm{id}=63398>$. Acesso em: 27 out. 2014.
CORDAZZO, S. T. D.; VIEIRA, M. L. A brincadeira e suas implicações nos processos de aprendizagem e de desenvolvimento. Estudos e Pesquisas em PsicologiaUERJ, Rio de Janeiro, v. 7, n. 1, p. 92-104, 2007.

COSCRATO, G.; PINA, J. C.; MELLO, D. F. Utilização de atividades lúdicas na educação em saúde:uma revisão integrativa da literatura. Acta Paulista de Enfermagem, São Paulo, v. 23, n. 2, p. 257-263, 2010.

FERREIRA, J. V. B.; FERREIRA, S. M. B.; CASSEB, G. B. Perfil e conhecimento teórico de médicos e enfermeiros em parada cardiorrespiratória, município de Rio Branco, AC. Revista Brasileira Cardiologia, Rio de Janeiro, v. 25, n. 6, p. 464-470, 2012.

FLEISCHHACKL， R.; NUERNBERGER， A.; STERZ, F.; SCHOENBERG, C.; URSO T.; HABART, T.; MITTLBOECK, M.; CHANDRA-STROBOS, N. School children sufficiently apply life supporting first aid: a prospective investigation. Critical Care, London, v. 13, n. 4, 2009.

FLICK, U. Uma introdução à pesquisa qualitativa. 2. ed. Porto Alegre: Bookman, 2007.

GOMES, L. B.; MERHY, E. E. Compreendendo a educação popular em saúde: um estudo na literatura brasileira. Caderno Saúde Pública, Rio de Janeiro, v. 27, n. 1, p. 7-18, 2011.

IERVOLINO, A. S.; PELICIONI, M. C. F. Capacitação de professores para a promoção e educação em saúde na escola: relato de uma experiência. Revista Brasileira de Crescimento e Desenvolvimento Humano, São Paulo, v. 15, n. 2, p. 99-110, 2005.

LIRA, A. C. M.; MACHADO, A. F. M.; FASSINI, C. C. S. O. Professores e crianças no primeiro ano do ensino fundamental de nove anos: desafios e expectativas. Revista Contrapontos, Itajaí, v. 11, n. 2, p. 152-160, 2011.

LUZIA, M. F.; LUCENA, A. F. Parada cardiorrespiratória do paciente adulto no âmbito intrahospitalar: subsídios para a enfermagem. Revista Gaúcha Enfermagem, Porto Alegre, v. 30, n. 2, p. 328337, 2009. 
LYRA, P. F.; CORDEIRO, D. E. F.; GOIS, A. C. R.; MUNIZ, F. N.; LEÔNIDAS, G. M.; SOBRINHO, C. R. M. R. Programa de educação em reanimação cardiorrespiratória: ensinando a salvar vida. Revista Brasileira de Educação Médica, Rio de Janeiro, v. 26, n. 4, p. 570-573, 2012.

MIRANDA, J. D. L. O design de informação e os primeiros socorros: a aprendizagem de primeiros socorros por parte das crianças dos 8 aos 10 anos. 2011. 333 f. Dissertação (Mestrado em Design de Comunicação) - Universidade Técnica de Lisboa, Faculdade de Arquitetura, Lisboa, 2011.

OLIVEIRA, S. R. G.; WENDHAUSEN, A. L. P. (Re) significando a educação em saúde: dificuldades e possibilidades da Estratégia Saúde da Família. Trabalho Educação e Saúde, Rio de Janeiro, v. 12, n. 1,p. 129-147, 2014.

PERGOLA, A. M.; ARAUJO, I. E. M. O leigo e o suporte básico de vida. Revista da Escola de Enfermagem da USP, São Paulo, v. 43, n. 2, p. 335344, 2008.

RIBEIRO, A. C.; BATISTA, A. J. A influência da mídia na criança / pré-adolescente e a educomunicação como mediadora desse contato. In: ENCONTRO DE HISTÓRIA DA MÍDIA DA REGIÃO NORTE, 1., 2010, Palmas. Anais... Palmas, 2010. Disponível em: <http://www. ufrgs.br/alcar/noticiasdosnucleos/artigos/A $\% 20$ INFLUENCIA $\% 20$ DA $\% 20$ MIDIA $\% 20 \mathrm{NA} \% 20$ CRIANCA \%20PREADOLESCENTE $\% 20 \mathrm{E} \% 20$ A \%20EDUCOMUNICACaO $\% 20 \mathrm{COMO} \% 20$ MEDIADORA\%20DESSE\%20CONTATO.pdf $>$. Acesso em: 20 jan. 2014.

SANTOS, A. O.; RODRIGUES, L. S. Avaliação do conhecimento de enfermeiros sobre o atendimento do paciente em parada cardiorrespiratória. RecienRevista Científica de Enfermagem, São Paulo, v. 1, n. 1, p. 25-29, 2011.

SILVA, P. O.; OLIVEIRA, T. G. S.; MARTA, C. B.; FRANCISCO, M. T. R.; MARTIN, E. R. C.; SAMPAIO, C. E. P. Os alunos do ensino médio e o conhecimento sobre o suporte básico de vida. Revista de Enfermagem UERJ, Rio de Janeiro, v. 20, esp. 1, p. 621-624, 2012.
SILVA, T. Z. Avaliação na educação infantil: um breve olhar na avaliação da aprendizagem. Revista Thema, Pelotas, v. 9, n. 2, p. 1-14, 2012.

THE INTERNATIONAL FEDERATION OF RED CROSS AND RED CRESCENT SOCIETIES. First aid for a safer future - focus on Europe. 2010. Disponível em: <http://www.ifrc.org/what/health/ firstaid/172300-First\%20Aid-Report-EN-LR.pdf>. Acesso em: 27 out. 2014. 